\title{
Ovulation and Embryonic Developmental Rate Following hCG-stimulation in Sows
}

\author{
By A. K. Nissen ${ }^{1,2,3}$, M. Schmidt ${ }^{2}$, P. Hyttel $^{l}$ and T. Greve ${ }^{2}$
}

${ }^{1}$ Department of Anatomy and Physiology, and ${ }^{2}$ Department for Clinical Studies, Reproduction, The Royal Veterinary and Agricultural University, Frederiksberg, and ${ }^{3}$ National Committee of Pig Breeding, Health and Production, Copenhagen, Denmark.

\begin{abstract}
Nissen AK, Schmidt M, Hyttel P, Greve T: Ovulation and embryonic developmental rate following hCG-stimulation in sows. Acta vet. scand. 2000, 41, 321328. - The hCG induced ovulation in sows was studied by use of ultrasonography, and an investigation of the development and diversity of the zygotes/embryos was performed at $24 \mathrm{~h}$ after ovulation. Crossbred sows $(\mathrm{N}=48)$ were weaned (day 0$)$ and checked for heat twice daily from day 3 onwards. From day 4 , the ovaries were transrectally scanned twice daily. On day 4 , the sows were given an injection of 750 iu hCG im and inseminated $27 \pm 2 \mathrm{~h}(\mathrm{X} \pm \mathrm{SD})$ and $38 \pm 1 \mathrm{~h}$ later. From 38 to $48 \mathrm{~h}$ after the $\mathrm{hCG}$ injection, the ovaries were scanned at 60 to 90 min intervals. At $24 \mathrm{~h}$ after ovulation the oviducts were surgically flushed in 18 sows. Out of the 48 sows, 34 showed heat at 12 $36 \mathrm{~h}$ after the hCG-treatment and 14 showed heat before the hCG treatment. In the former group of sows, $20(59 \%)$ ovulated within the interval of 38 to $48 \mathrm{~h}$ after the hCG treatment, and the follicular size immediately before ovulation was $7.8 \pm 0.6 \mathrm{~mm}$. Among the sows which showed heat before hCG treatment only $7(50 \%)$ ovulated within the above interval and the preovulatory follicle size was larger $(8.3 \pm 0.5, \mathrm{p}<0.05)$ than in the former group of sows, which showed heat after the hCG treatment. The flushing of 18 sows yielded a total of 243 ova, 70 (29\%) 1-cell stages, $160(66 \%) 2$-cell stages and $13(5 \%)$ 4-cell stages. A pronounced difference in the degree of variation in embryonic development was seen between sows: 4 animals yielded 1- to 4-cell stages, one exclusively 2-cell stage. In conclusion, the control of ovulation in sows by hCG treatment will affect the follicular growth and the exact timing of ovulation can not always be relied on. It is strongly recommended to use ultrasonography to monitor the time of ovulation if this parameter is important. Ova recovered at $24 \pm 1 \mathrm{~h}$ after the median time of ovulation revealed a pronounced diversity (1- to 4- cell stage) within sows. No obvious relation with this embryonic diversity and the follicular size at ovulation was seen in these data.
\end{abstract}

embryonic diversity; transrectal ultrasonography; follicular growth; embryo collection; onset of heat.

\section{Introduction}

In pig production the litter size is of great economic importance. This crucial parameter is mainly dependent on the rates of ovulation and embryonic mortality, as the fertilization rate is assumed to be $95 \%$ to $100 \%$ (Hunter $1967 \&$ 1972, Polge 1978).
The frequency of embryonic mortality is reported to be $30 \%$ to $50 \%$ (Pope \& First 1985), but the mechanisms behind it are poorly understood. Experiments indicate that developmental asynchrony, known as diversity, within the litter may disturb the embryo-uterus interaction for 
some embryos, causing the loss of the least developed embryos (Pope et al. 1990).

This concept has stimulated research in mapping of both the developmental rates of the porcine embryo and of the degree of diversity within a litter at different stages of development. The degree of diversity varies greatly between as well as within breeds and is seen at all stages of development (Van der Lende et al. 1994). Further insight into causes and the degree of embryonic diversity during embryonic development might add to the understanding of the background of this phenomenon.

Pope et al. (1990) evaluated the different factors, which could affect embryo development and lead to diversity and concluded that the oocyte and follicular maturation, the process of ovulation, and the expression of the embryonic genotype, were the factors most likely to be involved. The process and duration of ovulation have been found not to have any measurable affect on embryonic diversity (Soede et al. 1992, Van der Lende et al. 1994). This is in agreement with Xie et al. (1990), who showed that the diversity found during oocyte maturation was comparable to that found among zygotes after fertilization. However, they used onset of heat as their reference point, which can give age variation of the zygotes due to the variation in time of ovulation after onset of heat (Soede et al. 1992, Nissen et al. 1997). As the age variation can have an impact of the degree of development of the zygotes, exact timing of the ovulation is crucial when investigating degree of diversity in zygotes between sows.

It is generally assumed that ovulation takes place about $40 \mathrm{~h}$ after injection of human chorionic gonadotropin (hCG). However, if the hCG is not given shortly before the endogenous surge of LH, deviations such as lack of heat signs and impaired follicular growth resulting in reduced follicular size at ovulation can be seen (Hunter 1976, Soede et al. 1992, Nissen et al. 1995). The reduced follicular size is likely to affect the final oocyte and follicular maturation and the subsequent quality of the ovulated oocytes (Hunter 1979, Grant et al. 1989, Wiesak et al. 1990), and according to Pope et al. (1990) it may have an impact on embryonic diversity. By giving the hCG injection late, around the onset of heat, the suppression of the final follicular growth and the possible effect on final oocyte and follicular maturation may be avoided (Nissen et al. 1995). On the other hand, this approach is combined with the risk that the endogenous LH-surge has already initiated follicular and oocyte maturation.

The objective of this study was to monitor the hCG induced ovulation and the size of the ovulatory follicles by the use of ultrasonography and to investigate the development and diversity of the zygotes/embryos at $24 \mathrm{~h}$ after the ovulation.

\section{Materials and methods \\ Animal treatment, heat detection and ultra- sonography}

Danish crossbred sows (Yorkshire, Landrace and Duroc, parity 2 to 9,180 to $250 \mathrm{~kg}$ bdw of which 48 were chosen on the basis of history of normal fertility and ultrasonography findings such as normal ovaries without cysts or fresh corpora lutea $(\mathrm{CL})$ ), were weaned 3 weeks after farrowing (day 0) and transported to the stable in experimental groups of 3-5 sows. Heat detection was carried out twice daily from days 3 to 6 . The onset of heat was defined as the first time the sow showed standing reflex in front of a boar in combination with swelling and reddening of the vulva. On day 4 , the sows were given an im injection of 750 iu hCG (Physex ${ }^{\circledR}$, Leo Pharmaceutical, Ballerup, Denmark) to induce ovulation.

From day 4, the ovaries of the sows were scanned morning and late afternoon by transrectal ultrasonography (Basic Scanner 150, 
Table 1: Time of ovulation and onset of heat in relation to hCG injection.

\begin{tabular}{|c|c|c|c|}
\hline & $\begin{array}{c}\text { Onset of heat before } \\
\text { or at hCG injection, } \\
\text { number (\%) }\end{array}$ & $\begin{array}{l}\text { Onset of heat after } \\
\text { hCG injection, } \\
\text { number (\%) }\end{array}$ & $\begin{array}{c}\text { Total } \\
\text { number } \\
(\%)\end{array}$ \\
\hline $\begin{array}{l}\text { Time of ovulation before expected interval } \\
\text { (before } 38 \mathrm{~h} \text { after hCG injection) }\end{array}$ & $\begin{array}{c}7^{\mathrm{a}} \\
(50) \\
\end{array}$ & $\begin{array}{r}13^{\mathrm{b}} \\
(38)\end{array}$ & $\begin{array}{c}20 \\
(42)\end{array}$ \\
\hline $\begin{array}{l}\text { Time of ovulation in expected interval } \\
\text { ( } 38 \text { to } 48 \mathrm{~h} \text { after hCG injection) }\end{array}$ & $\begin{array}{c}7 \\
(50)\end{array}$ & $\begin{array}{c}20 \\
(59)\end{array}$ & $\begin{array}{l}27 \\
(56)\end{array}$ \\
\hline $\begin{array}{l}\text { Time of ovulation after expected interval } \\
\text { ( } 48 \text { to } 64 \mathrm{~h} \text { after hCG injection) }\end{array}$ & 0 & $\begin{array}{c}1 \\
(3)\end{array}$ & $\begin{array}{c}1 \\
(2)\end{array}$ \\
\hline Total & $\begin{array}{c}14 \\
(100)\end{array}$ & $\begin{array}{c}34 \\
(100)\end{array}$ & $\begin{array}{c}48 \\
(100)\end{array}$ \\
\hline
\end{tabular}

a,b) The numbers of sows ovulating before $38 \mathrm{~h}$ after the hCG injection are significantly different from zero.

multiangle probe 5.0/7.5 Mhz, Pie Medical ${ }^{\circledR}$, Maastricht, The Netherlands) as described by Nissen et al. (1995). The number of follicles and the average diameter of 3-5 follicles, representative for the ovary, were noted together with any features deviating from the expected normal ultrasonographic findings. From 38 to $48 \mathrm{~h}$ after the hCG injection the ovaries were scanned at 60 to $90 \mathrm{~min}$ intervals until the time and duration of the ovulation wave had been determined. The duration of the ovulation wave was roughly defined as the interval between the last scanning at which the maximum number of follicles was recorded and the scanning with no presumptive ovulatory follicles left. The median time of ovulation was defined as the midpoint of this interval. For sows ovulating before $38 \mathrm{~h}$ post hCG treatment, the time and duration of the ovulation was not monitored. If no ovulation had taken place at $48 \mathrm{~h}$ after the hCG injection, the sows were scanned once daily until ovulation had occurred.

The sows were inseminated twice at $27 \pm 2 \mathrm{~h}$ and $38 \pm 1 \mathrm{~h}$ after hCG injection with semen from the same Landrace boar. The semen was collected and controlled at the AI-station $\left(2.0 \times 10^{9}\right.$ sperm per dose $)$.
Collection of presumptive zygotes and embryos The sows which ovulated in the interval 38 to $48 \mathrm{~h}$ after hCG injection were operated on at 24 $\pm 1 \mathrm{~h}$ after median time of ovulation (day 7). The sows $(\mathrm{N}=18)$ were given azaperonum 800 mg IM (Sedaperone ${ }^{\circledR}$ vet., Janssenpharm, Birkerød, Denmark, $40 \mathrm{mg} / \mathrm{ml}$ ) as a sedative, and $30 \mathrm{~min}$ later the sows were submitted to general anaesthesia with thiopental (Pentothal ${ }^{\circledR}$, Abbot, North Chicago, USA, $15 \mathrm{mg} / \mathrm{kg}$ bdw). Each oviduct was flushed with $2 \times 20 \mathrm{ml}$ of phosphate buffered saline (PBS, Dulbeccos) supplemented with $1 \%$ heat inactivated fetal calf serum (flushing medium) at $38^{\circ} \mathrm{C}$ through a flank incision. The uterus wall was penetrated by a blunt needle ( 16 or $18 \mathrm{G}$ ) which was further pushed through the utero-tubal junction. The needle was connected to a syringe containing $20 \mathrm{ml}$ of flushing medium, which was flushed from the uterus tubal junction to the infundibulum, where a catheter collected the flushing medium.

Following flushing, the presumptive zygotes and embryos were isolated and evaluated under a stereomicroscope $(100 \times$ to $320 \times)$. Their total number and their stage of development (1-4 cells) were recorded. Ova displaying shrinkage 
Table 2: Medium time of ovulation and duration of the ovulation wave in sows ovulating 38 to $48 \mathrm{~h}$ after hCG injection (mean \pm standard deviation [range]).

\begin{tabular}{lccccc}
\hline & $\begin{array}{c}\text { Number of } \\
\text { sows (N) }\end{array}$ & $\begin{array}{c}\text { Interval from onset } \\
\text { of heat to medium } \\
\text { time of ovulation (h) }\end{array}$ & $\begin{array}{c}\text { Interval from hCG } \\
\text { injection to medium } \\
\text { time of ovulation (h) }\end{array}$ & $\begin{array}{c}\text { Max. Size } \\
\text { of follicles } \\
\text { (mm) }\end{array}$ & $\begin{array}{c}\text { Duration of } \\
\text { ovulation } \\
\text { wave (h) }\end{array}$ \\
\hline $\begin{array}{l}\text { Onset of heat before hCG } \\
\text { injection }\end{array}$ & 7 & $\begin{array}{c}42.4 \pm 3.1 \\
{[39 \text { to } 48]}\end{array}$ & $\begin{array}{c}40.6 \pm 1.8 \\
{[381 / 2 \text { to 44] }}\end{array}$ & $\begin{array}{c}8.3 \pm 0.5 \\
{[8-9]}\end{array}$ & $\begin{array}{c}1.9 \pm 0.8 \\
{[1 \text { to 3] }}\end{array}$ \\
\hline $\begin{array}{l}\text { Onset of heat after hCG } \\
\text { injection }\end{array}$ & 20 & $\begin{array}{c}24.4 \pm 3.2 \\
{[18 \text { to } 281 / 2]}\end{array}$ & $\begin{array}{c}41.2 \pm 1.6 \\
{[381 / 2 \text { to } 44]}\end{array}$ & $\begin{array}{c}7.8 \pm 0.6 \\
{[7-8]}\end{array}$ & $\begin{array}{c}2.4 \pm 1.2 \\
{[1 \text { to 4] }}\end{array}$ \\
\hline Total & 27 & $29.1 \pm 8.6$ & $41.0 \pm 1.6$ & $7.9 \pm 0.6$ & $2.3 \pm 1.1$ \\
& & {$[18$ to 48] } & {$\left[38 \frac{1}{2}\right.$ to 44] } & {$[7-9]$} & {$[1$ to 4] } \\
\hline
\end{tabular}

or excessive granulation were considered as degenerated. Ova without spermatozoa in the zona pellucida were considered as being nonfertilized.

\section{Statistics}

The distributions of ovulation frequencies were compared using the chi-square test. The data in the text are indicated as $\mathrm{X} \pm \mathrm{SD}$ [range]. All other data are only presented descriptively as mean $(\mathrm{X})$ and [range].

\section{Results \\ Heat control and ultrasonography}

In 14 out of the 48 sows monitored, the onset of heat was seen before or at the time of hCG injection, whereas in 34 sows heat was not detected until 12 to $36 \mathrm{~h}$ after the injection (Table 1). Noticeably, only 27 sows ovulated at 38 to $48 \mathrm{~h}$ after the hCG injection, and in these animals the time and duration of the ovulatory wave was monitored and showed that median time of ovulation occurred $41.0 \pm 1.6 \mathrm{~h}$ after the hCG injection and the duration of the ovulation

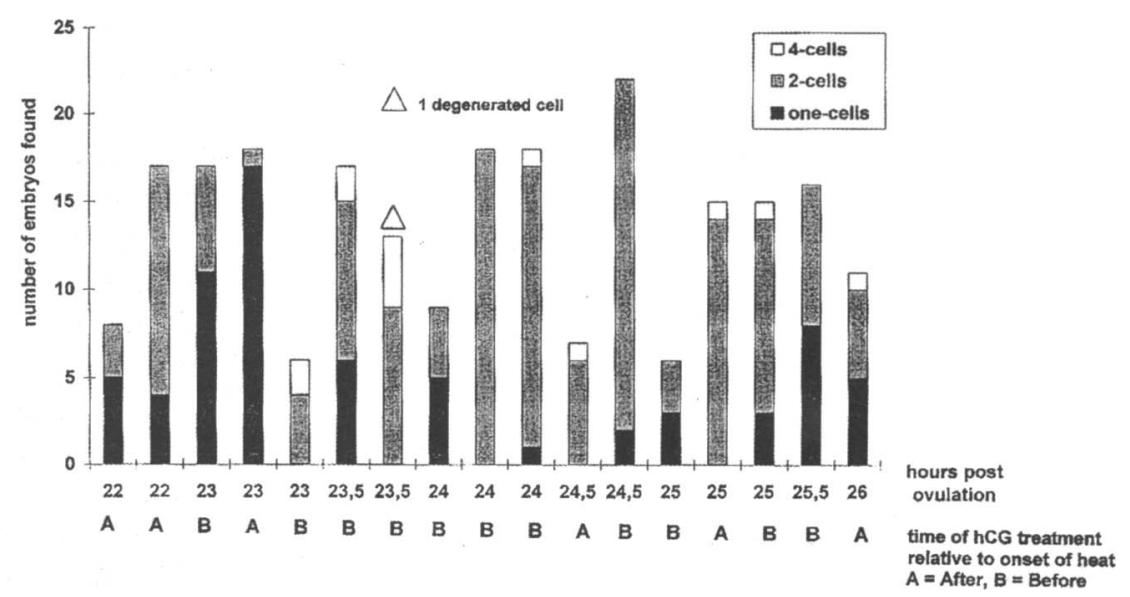

Figure 1: Developmental stages of embryos recovered 22-26 h post ovulation from 17 sows. (Each column represents 1 sow). 
Table 3: Connection between duration of ovulation, follicle size at ovulation and developmental stage of ova recovered approx. $24 \mathrm{~h}$ after ovulation.

\begin{tabular}{|c|c|c|c|c|c|c|c|c|}
\hline \multirow[t]{2}{*}{ Sow No. } & \multirow{2}{*}{$\begin{array}{l}\text { Time of hCG } \\
\text { treatment } \\
\text { relative to } \\
\text { onset of heat }\end{array}$} & \multirow{2}{*}{$\begin{array}{l}\text { Time after } \\
\text { ovulation } \\
\text { (h) }\end{array}$} & \multicolumn{4}{|c|}{ Developmental stage (number) } & \multirow{2}{*}{$\begin{array}{c}\text { Size of } \\
\text { follicles } \\
\text { at ovulation } \\
(\mathrm{mm})\end{array}$} & \multirow{2}{*}{$\begin{array}{l}\text { Duration of } \\
\text { ovulation } \\
\text { wave } \\
\text { (h) }\end{array}$} \\
\hline & & & one-cell $(\mathrm{N})$ & 2 -cell $(\mathrm{N})$ & 4-cell $(\mathrm{N})$ & total $(\mathrm{N})$ & & \\
\hline $16^{\text {a) }}$ & After & $22 \mathrm{~h}$ & 5 & 3 & - & 8 & $8[8]$ & 1 \\
\hline 19 & After & $22 \mathrm{~h}$ & 4 & 13 & - & 17 & $7.3[7-8]$ & $1 \frac{1}{2}$ \\
\hline 14 & Before & $23 \mathrm{~h}$ & 11 & 6 & - & 17 & $7.3[7-8]$ & 2 \\
\hline 45 & After & $23 \mathrm{~h}$ & 17 & 1 & - & 1 & $8[8]$ & 1 \\
\hline 10 & Before & $23 \mathrm{~h}$ & - & 14 & 2 & 16 & $7.3[7-8]$ & 4 \\
\hline 13 & Before & $231 / 2 \mathrm{~h}$ & 6 & 9 & 2 & 17 & $7.3[7-8]$ & 1 \\
\hline 383 & Before & $231 / 2 \mathrm{~h}$ & - & 9 & 4 & 13 & 7 [7] & $11 / 2$ \\
\hline 24 & Before & $24 \mathrm{~h}$ & 5 & 4 & - & 9 & $8[7-9]$ & $21 / 2$ \\
\hline 21 & Before & $24 \mathrm{~h}$ & - & 18 & - & 18 & $7[7]$ & $2 \frac{1}{2}$ \\
\hline 47 & Before & $24 \mathrm{~h}$ & 1 & 16 & 1 & 18 & $7.3[7-8]$ & $1 \frac{1}{2}$ \\
\hline $26^{\mathrm{b})}$ & After & $24 \frac{1}{2} \mathrm{~h}$ & - & 6 & 1 & 7 & $7.7[7-8]$ & 3 \\
\hline 29 & Before & $24 \frac{1}{2} \mathrm{~h}$ & 2 & 20 & - & 22 & $7[7]$ & $1 \frac{1}{2}$ \\
\hline 23 & Before & $25 \mathrm{~h}$ & 3 & 3 & - & 6 & $7.3[7-8]$ & 3 \\
\hline 41 & After & $25 \mathrm{~h}$ & - & 14 & 1 & 15 & $8[7-9]$ & $1 \frac{1}{2}$ \\
\hline 4140 & Before & $25 \mathrm{~h}$ & 3 & 11 & 1 & 15 & $7[7]$ & $1 \frac{1}{2}$ \\
\hline 2 & Before & $25^{1 / 2 h} \mathrm{~h}$ & 8 & 8 & - & 16 & $7.3[7-8]$ & 4 \\
\hline 4054 & After & $26 \mathrm{~h}$ & 5 & 5 & 1 & 11 & $7.6[7-9]$ & 1 \\
\hline
\end{tabular}

a) The left oviduct was not flushed due to a block. b) Only cysts were observed at the right ovary.

wave was on average $2.3 \pm 1.1 \mathrm{~h}$ (Table 2 ). The maximum number of follicles counted by ultrasonography per sow was on average $17.2 \pm 3.8$. The average maximum follicle size monitored at the last scanning before ovulation was $7.9 \pm$ $0.6 \mathrm{~mm}$. However, when hCG was given at or after the onset of heat the follicles were significantly $(\mathrm{p}<0.05)$ larger than when hCG was given before onset of heat $(8.3 \pm 0.5 \mathrm{~mm}$ vs 7.8 $\pm 0.6 \mathrm{~mm}$ respectively).

In 20 sows ovulating before and 1 sow ovulating after the expected time frame of $38 \mathrm{~h}$ to 48 $\mathrm{h}$ after the hCG treatment, the time and duration of the ovulatory wave was not monitored.

\section{Embryo collection}

A total of 18 sows were operated $24 \pm 1 \mathrm{~h}$ after median time of ovulation. The flushing of 17 of the 18 sows yielded a total of 243 embryos, all with spermatozoa in the zona pellucida. A single ovum was considered generated (Fig.1). The average recovery rate in these sows was $89 \% \pm 17 \%$, and of these embryos $70(29 \%)$ were at the 1 -cell stage, $160(66 \%)$ at the 2 -cell stage and $13(5 \%)$ at the 4-cell stage (Table 3 and Fig. 1). Flushing of the remaining sow resulted in the recovery of 12 unfertilised 1-cell stages without spermatozoa in the zona pellucida. Examination of the uterus revealed block of the lumen in both uterine horns.

A pronounced difference in diversity of embryonic development was noticed between sows. Thus, 4 animals yielded 1-4-cell embryos while one animal yielded exclusively 2-cell stage (Table 3 and Fig. 1). 


\section{Discussion}

The time from hCG injection to ovulation is reported to vary both between and within breeds depending upon several factors (Polge 1978, Hunter 1979). In general, ovulation is expected to occur 38 to $46 \mathrm{~h}$ after injection. We gave the hCG injection on day 4 to assure growth of the follicles to a normal preovulatory size (Nissen et al. 1995). But, when giving the hCG injection late i.e. after the onset of heat, a large proportion of the sows will ovulate at an unpredictable time, before the expected hCG induced ovulation. However, our use of ultrasonography with the 60-90 min. interval allowed determination of the time of ovulation with similar accuracy, despite the late hCG injection. We found that, if the hCG injection was given in proestrus, 12 to $36 \mathrm{~h}$ before onset of heat, only $59 \%$ of the sows ovulated within the interval 38 to 48 $\mathrm{h}$ after injection. If the $\mathrm{hCG}$ injection was given as late as at the beginning of oestrus, after the onset of heat, only $50 \%$ of the sows ovulated within this interval.

The considerable number of sows ovulating before the expected time in both groups underline the fact that the relative late hCG treatment of sows is inaccurate for precise prediction of the time of ovulation, eg. for synchronous embryo transfer or production of zygotes for genetic manipulation. In experimental design where timing of the ovulation is essential it is highly recommended to use ultrasonography to monitor the time of ovulation.

The unpredictability of the timing of the ovulation after a late hCG injection, i.e. injection after the onset of heat, is probably due to the fact that the endogenous LH surge has already induced the ovulation and the final follicular maturation. On the contrary, when the hCG treatment is administered early, i.e. before the onset of heat, final follicular maturation is induced by the hCG.

In the latter cases final follicular maturation is induced at a smaller follicular size, resulting in consequently smaller follicles at the time of ovulation (Table 2).

A relationship between the follicular size at ovulation, the duration of ovulation and the development of the embryos flushed at $24 \mathrm{~h}$ after the ovulation could not be established (Table 3).

Previous investigations of the chronology of porcine embryonic development have been based upon time scales starting at the onset of heat (Heuser \& Streeter 1929, Cassar et al. 1994), insemination (Hunter 1974), or hCG-injection (Hunter et al. 1993). Considering the data discussed above, the latter parameter is apparently not accurate. The duration of heat and the time of ovulation relative to the onset of heat also vary among sows even within the same breed (Soede et al. 1995). Accordingly, in another experiment (Nissen et al. 1997) we found the average duration of heat to be $60 \pm 13$ $h$ (range: $30-89, n=118$ ) and the interval from onset of heat to ovulation to be $42 \pm 11 \mathrm{~h}$ (range: 17-68, $\mathrm{n}=118$ ). Thus, the postovulatory age of ova collected at a fixed time interval after the onset of heat would in that case differ up to $51 \mathrm{~h}$, which renders the onset of heat an unprecise measure of ovulation time. Hunter (1974) reported that the first cleavage occurs at 14 to $16 \mathrm{~h}$ after activation, which, however, was not precisely defined in relation to clinical signs or other events. Our results, obtained by flushing of ova at $24 \pm 1 \mathrm{~h}$ after the median time of ovulation clearly demonstrated that a difference in the rate of embryonic development exists within the litter of the individual sow.

The relationship between the difference in rate of embryonic development and the sizes of the ovulatory follicles could not be established.

In conclusion, the control of ovulation in sows hCG treatment at day 4 post weaning may affect the follicular growth and the exact timing of ovulation can not be estimated in half of the sows. It is strongly recommended to use ultrasonogra- 
phy to monitor the time of ovulation if this parameter is important.

Ova recovered $24 \pm 1 \mathrm{~h}$ after the median time of ovulation revealed a pronounced diversity ( 1 - to 4-cell stage) within sows. Moreover, administration of hCG before onset of heat, results in decreased follicular size at the time of ovulation.

\section{Acknowledgements}

The author thanks Ms. Inger Heinze and Ms. Anna Marie Larsen for technical assistance. The work was supported by The Research Secretariat under the Danish Ministry of Agriculture.

\section{References}

Cassar G, King WA, King GJ: Influence of sex on early growth of pig conceptuses. J. Reprod. Fertil. 1994, 101, 317-320.

Grant SA, Hunter MG, Foxcroft GR: Morphological and biochemical characteristics during ovarian follicular development in the pig. J. Reprod. Fertil. 1989, 86, 171-183.

Heuser $C H$, Streeter GL: Early stages in the development of pig embryos, from the period of initial cleavage to the time of the appearance of limbbuds. Contri. Embryo. Carwg. Inst. 1929, 20, 130.

Hunter MG, Biggs C, Foxcroft GR, McNeilly AS, Tilton JE: Comparisons of endocrinology and behavioral events during the periovulatory period in Meishan and Large-White hybrid gilts. J. Reprod. Fertil. 1993, 97, 475-480.

Hunter RHF: The effect of delayed insemination on fertilization and early cleavage in the pig. J. Reprod. Fertil. 1967, 13, 133-147.

Hunter RHF: Fertilization in the pig: sequence of nuclear and cytoplasmic events. J. Reprod. Fertil. 1972, 29, 395-405.

Hunter RHF: Chronological and cytological details of fertilization and early embryonic development in the domestic pig, sus scrofa. Anat. Rec. 1974, 178, 169-186.

Hunter RHF: Dissociation of response to injected gonadotropin between the Graafian follicle and oocyte in pigs. Nature 1976, 260, 156-158.

Hunter RHF: Ovarian follicular responsiveness and oocyte quality after gonadotrophic stimulation of mature pigs. Annual Biology animal Biochemic Biophysiology. 1979, 19, 1511-1520.
Nissen AK, Lehn-Jensen H, Hyttel P, Greve T: Follicular Development and Ovulation in Sows: Effect of hCG and GnRH Treatment. Acta vet. scand. 1995, 36, 123-133.

Nissen AK, Soede NM, Hyttel P, Schmidt M, D'Hoore $L$ : The influence of time of insemination in relation to time of ovulation on farrowing rate and littersize in sows, investigated by ultrasonography. Theriogenology, 1997, 47, 1571-1582.

Polge C: Fertilization in the pig and horse. J. Reprod. Fertil. 1978, 54, 461-470.

Pope WF, First NL: Factors affecting the survival of pig embryos. Theriogenology. 1985, 23, 91-105.

Pope WF, Xie S, Broermann DM, Nephew KP: Causes and consequences of early embryonic diversity in pigs. J. Reprod. Fertil. 1990, Suppl. 40, 251-260.

Soede NM, Noordhuizen JPTM, Kemp B: The duration of ovulation in pigs, studied by transrectal ultrasonography, is not related to early embryonic diversity. Theriogenology. 1992, 38, 653-666.

Soede NM, Wetzels CCH, Zondag W, de Konning MAI, Kemp B: Effects of time of insemination relative to ovulation, as determined by ultrasonography, on fertilization rate and accessory sperm count in sows. J. Reprod. Fertil. 1995, 104, 99-106.

van der Lende T, Soede NM, Kemp B: Embryo mortality and prolificacy in the pig. In: Cole DJA, Wiseman J, Varley MA (eds): Principles of pig science. Notthingham Univercity Press, 1994, 16, 297-317,

Wiesak T, Hunter MG, Foxcroft GR: Differences in follicular morphology, steroidogenesis and oocyte maturation in naturally cyclic and PMSG/hCG-treated prepubertal gilts. J. Reprod. Fertil. 1990, 89, 633-641.

Xie S, Broermann DM, Nephew KP, Bishop MD, Pope $W F$ : Relationship between oocyte maturation and fertilization on zygote diversity in swine. J. Anim. Sci. 1990, 68, 2027-2033.

\section{Sammendrag}

Ovulation og embryo udviklingsgrad ved hCG stimulering $i$ søer.

Follikelstørrelse samt ovulationens varighed og tidspunkt blev undersøgt v.h.a. ultralydscanning hos søer i forbindelse med hCG induceret ovulation. Derefter blev embryonernes udviklingsstadium og diversitet vurderet 24 timer efter ovulationen. Krydsningsøer $(\mathrm{N}=48)$ blev fravænnet (dag 0), og brunstkontrol 
blev udført 2 gange dagligt fra dag 3 . Fra dag 4 blev ovarierne ultralydscannet 2 gange dagligt. På dag 4 fik søerne en injektion med 750 ie hCG im og blev insemineret $27 \pm 2$ og $38 \pm 1$ timer efter. Fra 38-48 timer efter hCG injektionen blev scanningen udført med 60-90 min. interval. Fireogtyve timer efter ovulationen blev æggelederne på 18 søer skyllet kirurgisk. Af de 48 søer viste 34 brunst 12-36 timer efter hCG behandlingen, og 14 viste brunst før hCG behandlingen. I den første gruppe af søer ovulerede 20 $(59 \%)$ indenfor intervallet 38 - 48 timer efter hCG injektionen, og follikelstørrelsen umiddelbart før ægløsningen var 7,8 $\pm 0,6 \mathrm{~mm}$. Af de søer, der viste brunst før hCG behandlingen, ovulerede $7(50 \%)$ indenfor det ovennævinte interval, og den preovulatoriske follikelstørrelse var større $(8,3 \pm 0,5 \mathrm{~mm}$, $\mathrm{p}<0,05)$. Ved skylning af 18 søer blev fundet 243 ova fordelt som; $70(29 \%)$ 1-cellestadie, $160(66 \%) 2$ cellestadie og $13(5 \%)$ 4-cellestadier. En udtalt forskel i udviklingstadium sås såvel indenfor som imellem søer: Fire søer gav 1-4 cellestadier, mens en anden udelukkende gav 2-cellestadier. Det kan konkluderes, at kontrol af ovulationen hos søer med hCG injektion ikke altid er tidsmæssig præcis, og at hCG behandlingen endvidere kan påvirke follikelvæksten. Det anbefales stærkt at benytte ultralyd til scanning af ovulationstidspunktet, hvis denne parameter er af betydning. Embryoner opsamlet $24 \pm 1$ timer efter ovulationen viste en udtalt diversitet (1- til 4-cellestadier) indenfor og imellem søer. Ingen tydelig relation mellem denne diversity og follikel størrelse ved ovulationen kunne ses ud fra resultaterne.

(Received June 17, 1998; accepted Maj 1, 1999).

Reprints may be obtained from: M. Schmidt, Department of Clinical Studies, Section of Reproduction, The Royal Veterinary and Agricultural University, Dyrlægevej 68, DK-1870 Frederiksberg C, Denmark. 